\title{
Meta-profile and competencies for harmonisation of higher education in sector-specific technology areas: A case study of Renewable Energy in Southern Africa
}

\author{
Wilfried Zörner, Nawaz Mahomed, Ackim Zulu, Tobias Bader, \\ Chifundo Tenthani, Boaventura Cuamba, and Hilton Chingosho*
}

doi: http://dx.doi.org/10.18543/tjhe-8(1)-2020pp75-97

Received: 24 June 2019

Accepted: 5 October 2020

\begin{abstract}
The aim of this study was to develop the profile and competencies of a harmonised curriculum for a multi-country regional sector-specific higher education programme. The study, which was based on a case study of Renewable Energy involving six countries in Southern Africa, was based on established methodologies proposed by previous studies on harmonisation and profiling of higher education programmes. The study uses a general curriculum development approach leading to
\end{abstract}

* Wilfried Zörner (Wilfried.Zoerner@thi.de), PhD in Mechanical Engineering (Solar Energy Systems), is Professor for Product Development and Design (since 1998) and Head of Institute at the Institute of new Energy Systems (InES) at Technische Hochschule Ingolstadt, Germany.

* Nawaz Mahomed (nawaz@sun.ac.za), PhD in Computational Mechanics, is Associate Professor in the Department of Mechanical and Mechatronic Engineering at Stellenbosch University, South Africa.

* Ackim Zulu (ackim.zulu@unza.zm), PhD in Electrical Machines, is Senior Lecturer in the Department of Electrical and Electronic Engineering at University of Zambia (UNZA), Zambia.

* Tobias Bader (badert@biust.ac.bw), PhD in Mechanical Engineering, is Lecturer in the Department of Mechanical, Energy and Industrial Engineering at Botswana International University of Science and Technology (BIUST), Botswana.

*Chifundo Tenthani (ctenthani@poly.ac.mw), Master of Science in Renewable Energy, is Senior Lecturer in the Department of Physics and Biochemical Sciences at the Malawi Polytechnic of the University of Malawi, Malawi.

* Boaventura Cuamba (boaventura.cuamba@gmail.com), PhD in Energy Physics, is Professor of Renewable Energy Systems at the Eduardo Mondlane University in Maputo, Mozambique.

* Hilton Chingosho (chingoshorus@gmail.com), Master of Science in Renewable Energy and $\mathrm{PhD}$ candidate, is Registered Engineer and Lecturer in the Department of Mechanical Engineering at the University of Zimbabwe, Zimbabwe.

More information about the authors is available at the end of this article. 
the definition of generic and specific competencies and feeding into a learning taxonomy to create alignment with specific learning outcomes at the intended qualification level. However, the approach extends the harmonisation concept to include industrialisation potential, which is crucial in the developing-country context. This allows for the exploitation of shared resources in sector-specific technology areas and supports the development of regional standards on technology and practice, as part of developing a sustainable regional economic sector. Twentytwo competencies, encompassing both generic and specific competencies, were defined. These competencies were grouped into six key competence areas, and later transformed into four clusters of competencies: core competencies, hard skills, soft skills and attitudes. These four clusters were then placed on a planetary system to represent the meta-profile for the qualification, which forms the framework for the future design of learning materials for the qualification.

Keywords: Harmonisation; generic competencies; specific competencies; metaprofile; curriculum development; renewable energy.

\section{Introduction}

Globally, degree programmes in technology-based fields are often complimented by industry-based post-degree internships, especially by large state-owned and private companies, and within environments with high levels of technology diffusion. This allows these programmes to be designed with a purely technology focus and a high emphasis on the basic sciences. Within the Southern African development context, however, the adoption of technologies is still facing many barriers that include inadequate technical capacity and an inexperienced professional workforce, as evidenced by the Technology Achievement Indices of countries in this region. ${ }^{1}$ In line with this, a considerable need for innovators and entrepreneurs to spur such new markets and industry development in developing countries has been cited. ${ }^{2}$ In this context, it is understood that the region suffers from a weak nucleation potential for competitive enterprises. For this reason, higher education programmes are necessary that target specific niche technology areas, together with a diversification of competencies to allow for the gaps in the developmental trajectory of graduates, so that new enterprises can be

\footnotetext{
1 Ahmet Incekara, Tugba Guz, and Gulden Sengun, "Measuring the Technology Achievement Index: Comparison and Ranking of Countries," Journal of Economics, Finance and Accounting 4, no. 2 (2017): 170-171, http://doi.org/10.17261/Pressacademia.2017.446.

2 REN21, "Renewables 2015 Global Status Report," https://www.ren21.net/wp-content/ uploads/2019/05/GSR2015_Full-Report_English.pdf.
} 
nucleated. At the same time, labour market orientation needs to be taken into consideration, which implies consultative inclusion of industrialisation potential (as opposed to purely industry needs) with regard to expertise, skills and competencies.

Higher education and vocational training institutions have therefore become key enablers in the development of these emerging technology sectors (or subsectors) in the region. This has seen an increase in the number of projects aimed at developing customised higher education programmes in Southern Africa, often with multi-country beneficiaries. These include programmes on space technology, ${ }^{3}$ smart grid technology ${ }^{4,5,6}$ water resource development and management, ${ }^{7}$ and wastewater treatment, ${ }^{8}$ to mention a few.

A further such emerging technology area, which has received extensive attention over the past few years, is that of renewable energy (RE), within the broader energy sector, where the existing potential for the exploitation of RE resources and technologies can still not be realised in the face of a growing demand for qualified workers in this emerging market in the region.

The RE sector is one of the most promising economic growth areas in the Southern African region due to the massive demand for electrification in off-

${ }^{3}$ Ganiyu Agbaje, Omowumi Alabi, and Etim Offiong, "Education and Training in Applied Remote Sensing in Africa: The ARCSSTE-E Experience," ISPRS International Journal of Geo-Information 8, no. 350 (2019): 3-10. https://doi.org/10.3390/ijgi8080350.

${ }^{4}$ Masoumeh Ebrahimi, Amleset Kelati, Emma Nkonoki, Aron Kondoro, Diana Rwegasira, Imed Ben Dhaou, Ville Taajamaa, and Hannu Tenhunen, "Creation of CERID: Challenge, Education, Research, Innovation, and Deployment in the Context of Smart MicroGrid," in Proceedings of the 2019 IST-Africa Week Conference (IST-Africa) (Nairobi, May 2019): 1-8.

${ }^{5}$ Edward Chikuni, Francisco Goncalves-Longatt, Emanuel Rashayi, and Ogbonnaya I. Okoro, "Power system, substation, automation and the smart grid, how should universities react?," in Proceedings of the IEEE International Conference on Industrial Technology (ICIT) (Cape Town, 2013): 906-907, https://doi.org/10.1109/ICIT.2013.6505791.

${ }^{6}$ Anthony Staak and Raynitchka Tzoneva, "The design of a master's curriculum in smart grid technology within the Erasmus+ K2 DAMOC project," in Proceedings of the 11th International Conference on Engineering and Business Education (ICEBE) (Szczecin, 2018): 27-34.

7 Mikko Martikka, Roope Husgafvel, Olli Dahl, Andrade Egas, and Natasha Ribeiro, "Study Module Development on Environmental Engineering - Experiences from Mozambican and Finnish Higher Education Collaboration," in Proceedings of the International Conference Environment and Water Resource Management (AfricaEWRM) (Gaborone, 2014): 35-43.

${ }^{8}$ Lewis Jonker, Pieter van der Zaag, Bekithemba Gumbo, Johan Rockström, David Love, and Hubert H. G. Savenije, "A regional and multi-faceted approach to postgraduate water education - the Watered experience in Southern Africa," Hydrology and Earth System Sciences, no. 16 (November 2012): 4227-4228, https://doi.org/10.5194/hess-16-4225-2012 
grid locations. Reports have shown that the development of RE-based microgrids in rural locations as well as larger scale RE infrastructure in urban areas will become a growing trend to meet the energy demand of Sub-Saharan Africa. ${ }^{9,10,11,12}$

This study uses the case of RE education at undergraduate level, under the DAAD-funded "Academic Initiative for Renewables" (AIR) project, with participating university partners in Botswana, Malawi, Mozambique, South Africa, Zambia and Zimbabwe, and Technische Hochschule Ingolstadt as the benchmarking partner.

In addition to the aforementioned, the harmonising of technology-based education programmes can further enhance enterprise nucleation potential due to intra-African industrialisation opportunities, which includes the extension of local country markets. This is a different view to that related to mobility and credit transfer, as initiated under the Arusha Convention of $1981^{13}$ until the more recent Tuning Africa Project ${ }^{14,15}$ which concluded in 2015, as well as ongoing efforts under the African Union Commission. ${ }^{16}$ Whilst the need for regional harmonisation of learning programmes has been recognised for purposes of internationalisation of higher education, learner mobility and credit transfer, and many studies have been undertaken to

9 IEA. "World Energy Outlook 2014," https://www.iea.org/reports/world-energyoutlook-2014.

${ }^{10}$ IRENA, "Renewable Energy in the Water, Energy \& Food Nexus," 2015, https://www. irena.org/publications/2015/Jan/Renewable-Energy-in-the-Water-Energy--Food-Nexus.

11 The World Bank, "State of Electricity Access Report (SEAR) 2017," https://documents. worldbank.org/en/publication/documents-reports/documentdetail/364571494517675149/fullreport.

12 REN21, "SADC Renewable Energy and Energy Efficiency Status Report," 2018, https://www .ren21.net/2018-sadc-renewable-energy-and-energy-efficiency-status-report/.

13 Ayenachew A. Woldegiyorgis, "Harmonization of higher education in Africa and Europe: Policy convergence at supranational level," Tuning Journal for Higher Education 5, no. 2 (May 2018): 144. http://dx.doi.org/10.18543/tjhe-5(2)-2018pp133-157.

14 Tuning Academy, "Feasibility Study into the Relevance of a Tuning Approach for Higher Education in Africa," Final Report, 2011, http://tuningacademy.org/tuning-africafeasibility-study/?lang=en

${ }^{15}$ Karola Hahn and Damtew Teferra, "Tuning as Instrument of Systematic Higher Education Reform and Quality Enhancement: The African Experience," Tuning Journal for Higher Education 1, no. 1 (2014): 127, http://dx.doi.org/10.18543/tjhe-1(1)-2013pp127-163.

${ }^{16}$ Emnet T. Woldegiorgis, Regionalization of Higher Education in Africa: The Operationalization of the African Union Higher Education Harmonization Strategy (Berlin: LIT Verlag, 2017): 173-187. 
harmonise general degree qualifications, ${ }^{17,18,19,20}$ this work focuses on a different need for harmonisation: the need to exploit intra-African economic development opportunities and access larger markets for economies of scale. This further points to the need for the development of regional standards on technology and practice, as part of developing sustainable regional economic sectors.

\section{Profile development methodology}

Education qualification frameworks (EQFs) of countries are not prescriptive about the methodology to be deployed, as long as certain programme development criteria are met. These criteria include stakeholder engagement, benchmarking and the level of the learning outcomes. Hence, in the context of the current study, the methodology must allow for a needs analysis within the national context of participating countries, to ensure relevance and policy alignment. This will need to include stakeholder engagement to establish a basis for the competencies and the professional profile linked to the qualification, as shown in Figure 1.

Methodologies for competence-based curriculum development, as used in this study, have been proposed by various authors. In particular, the work by Kouwenhoven, ${ }^{21}$ in the stages of assigning competencies to the knowledge, skills and attitudes (KSA) orbits (categories) and to the cognitive and

17 Julia González and Maria Yarosh, "Building Degree Profiles. The Tuning Approach," Tuning Journal for Higher Education 1, no. 1 (July 2014): 37, http://dx.doi.org/10.18543/tjhe1(1)-2013pp37-69.

18 Samuel M. Sackey et al., "Collaborative meta-profile development to harmonise mechanical engineering education in Africa," Tuning Journal for Higher Education 2, no. 1 (December, 2014): 161, http://dx.doi.org/10.18543/tjhe-2(1)-2014pp161-178.

${ }^{19}$ Emnet T. Woldegiorgis, "Conceptualizing Harmonization of Higher Education Systems: The Application of Regional Integration Theories on Higher Education Studies," Higher Education Studies 3, no. 2 (2013): 12. https://doi.org/10.5539/hes.v3n2p12.

${ }^{20}$ Ahmed Elamrani et al., "Meta-profile development using the Tuning Methodology to support Agricultural Sciences Training in Africa" (Powerpoint presentation, International Conference on Engineering Education and Research, Marrakesh, July 1-5, 2013), https://www. researchgate.net/publication/330545209_Meta-profile_development_using_the_Tuning _ Methodology_to_support_Agricultural_Sciences_Training_in_Africa.

${ }^{21}$ Wim Kouwenhoven, "Competence-based curriculum development in Higher Education: a globalised concept?," in Technology Education and Development, ed. Aleksandar Lazinica and Carlos Calafate (Rijeka: InTech Open, 2009), 3-6. 
knowledge dimensions in the manner of a widely applied taxonomy, ${ }^{22}$ represents a large convergence to the approach followed in this study. Furthermore, the study by De Vasconcelos Sampaio Suñé and De Armas Urquiza ${ }^{23}$ underlain by the competence-based methodology, is structured on the two principles of firstly constructing the curriculum design in a systemic approach, starting with a professional profile down to the lesson plan, and secondly infusing in these products curriculum elements that elicit intradisciplinary and interdisciplinary cohesion. In relation to this study, there is close similarity in the emphasis on graduate competence as the guiding principle. Additionally, this study emphasises and adds the elements of integration between the generic and specific competence areas, as part of the harmonisation process.

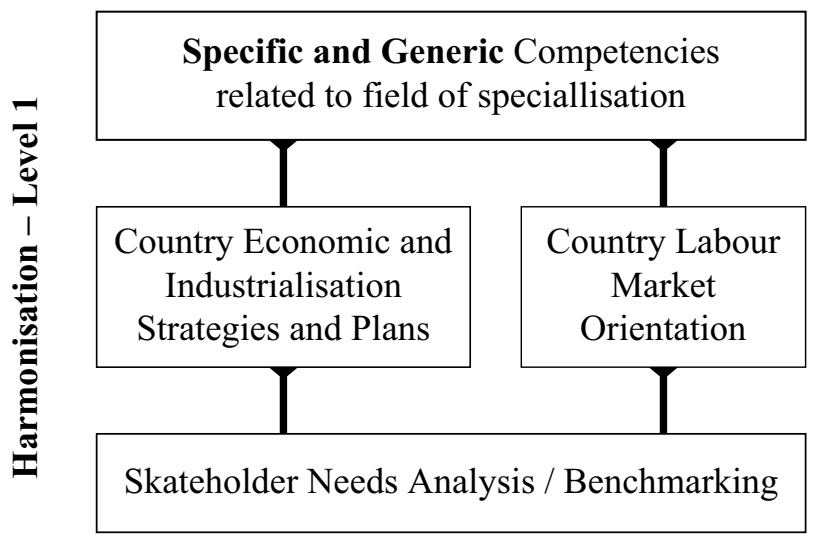

Figure 1

Harmonisation for industrialisation and labour market orientation

${ }^{22}$ Lorin W. Anderson, David R. Krathwohl, Peter W. Airasian, and Kathleen A. Kruikshank, A Taxonomy for Learning, Teaching, and Assessing: A Revision of Bloom's Taxonomy of Educational Objectives (New York: Longman, 2001).

${ }^{23}$ Letícia Soares de Vasconcelos Sampaio Suñé and Roberto de Armas Urquiza, "Compared education study: curriculum design for the development of competences," Tuning Journal for Higher Education 3, no. 2 (2016): 321. https://doi.org/10.18543/tjhe-3(2)2016pp319-346. 
Harmonisation as an integral part of degree programme development has received significant attention through the Tuning Higher Education in Africa pilot project, which highlighted the necessity of curricula harmonisation for improved academic competitiveness on the African continent. ${ }^{24}$ Studies emanating from this project used the Tuning approach for the harmonisation of undergraduate programmes in mechanical engineering across eleven universities in Africa, ${ }^{25}$ in Agricultural Sciences across twelve African countries ${ }^{26}$ among others, through synergising generic and specific competencies into a metaprofile. This challenge of harmonisation requires international cooperation and exchange, and multi-country initiatives (such as the present study) make harmonisation an intrinsic part of the curriculum development process in the definition of specific competencies. In this context, harmonisation for learner mobility and credit transfer, as part of the meta-profile development process, is linked to industrialisation and labour market orientation.

Engineering education must provide initial competencies for engineering work and developmental competencies for careers. ${ }^{27}$ The European Network for Accreditation of Engineering Education ${ }^{28}$ separates generic competencies from engineering-specific competencies. In this framework, Knowledge and Understanding, Engineering Analysis, Investigations and Engineering Practice are regarded as engineering-specific competencies, while Transferable Skills represent generic competencies.

In line with this, the next phase involves the evolution of the generic and engineering-specific competencies, followed by the classification of these competencies into main competence areas, eventually leading to the definition of a meta-profile for the qualification. The design of the curriculum in terms of learning materials, practice and assessments must then reflect the required learning outcomes at the level of the qualification, as required by the country EQFs, as depicted in Figure 2. In this sense, it is crucial that country EQFs are aligned, otherwise harmonisation of the higher degree programme across the participating countries will be a challenge.

${ }^{24}$ Karola Hahn and Damtew Teferra, "Tuning as Instrument of Systematic Higher Education Reform and Quality Enhancement: The African Experience," Tuning Journal for Higher Education 1, no. 1 (2014): 127, http://dx.doi.org/10.18543/tjhe-1(1)-2013pp127-163.

${ }_{25}$ Sackey et al., "Collaborative meta-profile development", 161.

${ }^{26}$ Elamrani et al., "Meta-profile development."

${ }^{27}$ Graham Elkin, "Competency-based human resource development," Industrial and CommercialTraining 22,no.4(April 1990):20-25.https://doi.org/10.1108/00197859010137009.

${ }^{28}$ ENAEE (European Network for Accreditation of Engineering Education), "EUR-ACE Framework Standards for the Accreditation of Engineering Programmes," 2018, https://www. enaee.eu/eur-ace-system/standards-and-guidelines/\#standards-and-guidelines-foraccreditation-of-engineering-programmes. 


\section{Harmonisation - Level 2}

Key Competence Areas:

An integrated set of skills or competencies that reflect the employment/work profiles of graduates, formulated from Work Skills Profiles.

Example:

- Capacity to conceive, analyse, design and manufacture sector-related products and systems, combined with

- Capacity to integrate legal, economic and financial aspects in decision-making in the sector-related projects.

Specific and Generic Competencies related to field of specialisation
Exit Level (Learning) Outcomes as per country EQFs

(e.g. Qualification Level 8 - South Africa)

- Apply knowledge at forefront of field of specialisation

- Critically review knowledge in field of specialisation, and develop creative solutions

- Methods/standards and procedures selection, application and transfer

- Identify, analyse and address complex problems in field of specialisation

- Ethics and Professional practice - critical reflection

- Accessing, processing and managing information - critically review in specialised contexts for creative solutions

- Producing and communicating information innovative insights and rigorous interpretations

- Operate effectively within a system

- Full responsibility; decision-making; full accountability.

Figure 2

Harmonisation for equivalence and comparability of qualifications across participant countries

In selecting the generic competencies in this study, consideration was given to areas that are considered generic within the engineering disciplines, as opposed to across all disciplines. This allows the specific competencies to be defined such that they build onto the generic competencies, leading to specialisation (for example, in the area of RE). Otherwise there would be a disjuncture or perceived irrelevance between the two sets of competencies.

Critical to the definition of the specific competencies, which could vary from country to country depending on resources and level 1 harmonisation, is engagement with stakeholders to establish the industrialisation and labour market needs (economic, technology, human resources, etc.). This automatically incorporates a gap analysis into the process and allows the region to benchmark itself against similar education programmes offered in other regions. 


\section{Renewable Energy (RE) education trends and needs in Southern Africa}

In applying the methodology outlined above, focusing on the need to develop generic and specific competencies for RE higher education harmonised across the region both in terms of industrialisation and labour market orientation, as well as compatibility of qualifications, an industry stakeholder survey was conducted. In order to generate representative results, the survey targeted professionals in the RE sector. A total of 85 responses representing various stakeholders across the region were received (Figure 3).

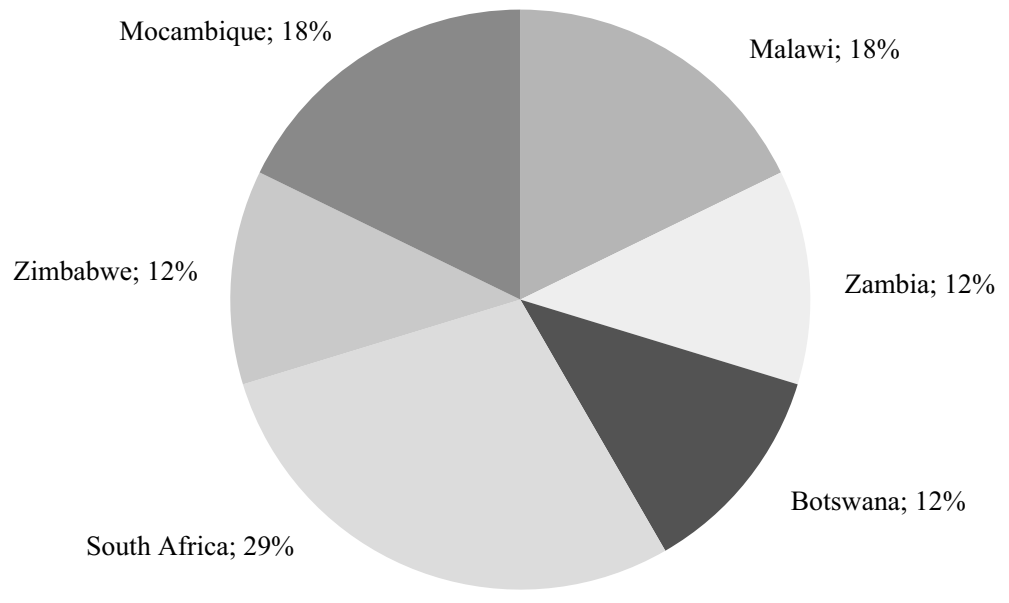

Figure 3

Distribution of respondents by country

Experienced RE professionals aged above 40 were strategically included together with young professionals in the age group 25 to $40(58.1 \%)$, to ensure that a spectrum of ideas and experiences were considered.

In order to better assess the lack of higher education programmes in RE in Southern Africa, the survey aimed to shed light on existing barriers in the sector. The study unveiled that a lack of funding (84\%) and poor exposure to RE at the introductory level of undergraduate studies (81\%) feature as dominant barriers to the delivery of RE education programmes (cf. Figure 4). 


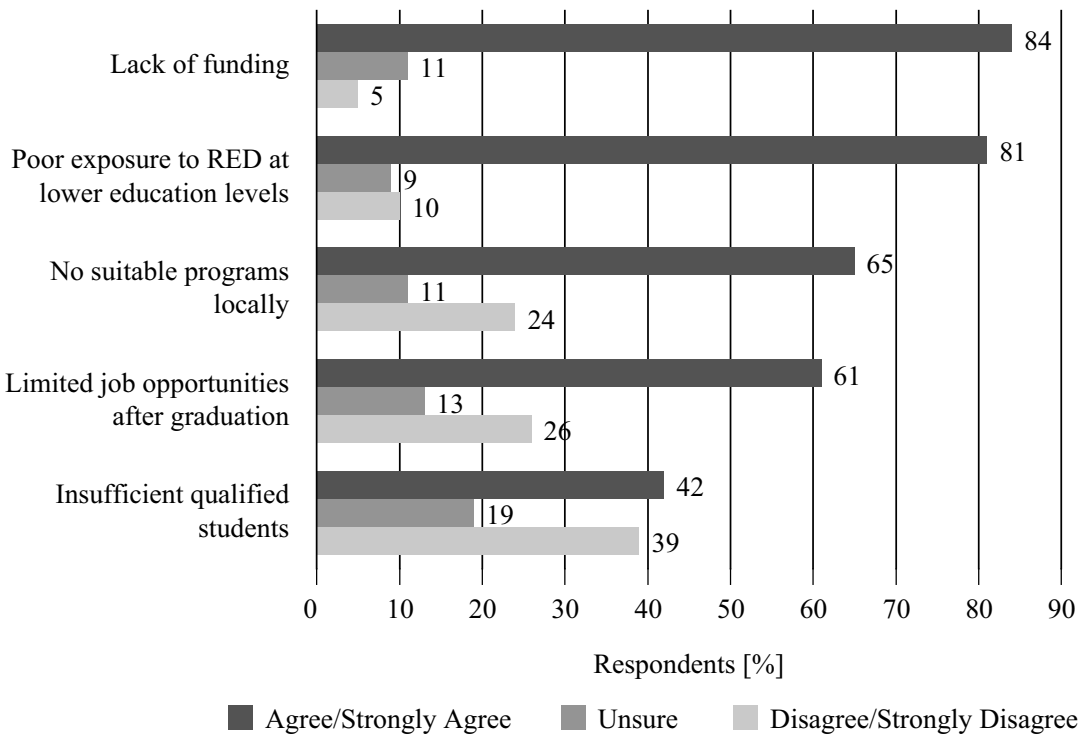

Figure 4

Barriers to delivery of RE education programs

The identified lack of funding was indicated as an obligation of governments. The poor exposure to the sector, on the one hand, predominantly pointed to the non-availability of scholarship support, and on the other hand, to a lack of internships and hands-on technology practices in introductory modules, the latter imparted mostly theoretically. As Figure 4 further shows, $65 \%$ of the respondents stated that there are no suitable study programmes in this area of technology in their respective countries; hence the need for a regional initiative to address this gap. These findings are in line with those of Pegels,${ }^{29}$ who argues that RE technologies lack in capacity at all levels of education. In terms of student qualifications, $39 \%$ of the respondents were convinced that students are not adequately qualified with basic skills (mathematics, physics, etc.), which challenges the assimilation of RE engineering skills by graduates in undergraduate study courses.

29 Anna Pegels, "Renewable energy in South Africa: Potentials, barriers and options for support," Energy Policy 38 (2010): 4945-4954, https://doi.org/10.1016/j.enpol.2010.03.077. 
The challenges that RE education is required to address are diverse; however, the survey showed that RE education is supposed to mostly address a lack of well-trained professionals, the need for development and implementation of required RE technologies and a lack of policies and regulatory standards. The data shows that the dominant challenge in all countries is the need for local development and implementation of state-ofthe-art technologies $(93 \%)$, which is interdependent with the identified lack of competent professionals in the field $(86 \%)$. Overcoming this lack of professionals will have a positive impact on the current lack of policies and standards (88\%), through increased capacity on national committees and in government departments responsible for the development of the sector.

The survey further sheds light on the type of education necessary for growth in the sector within the region. It is evident that all types of education opportunities (undergraduate, postgraduate, industry apprenticeships, vocational training and short courses) are principally important ( $>80 \%$ of respondents strongly agree or agree). Furthermore, in excess of $90 \%$ of the respondents regard undergraduate studies, postgraduate studies and industry apprenticeships as most important in imparting knowledge and competencies in this technology-intensive sector. This is in agreement with Jain et al (2002) ${ }^{30}$ who recommend the strengthening of practical components of RE in tertiary education.

In order to produce young engineers with quality competencies in RE, the majority of respondents indicated that the contents of RE programmes should be defined by industry ( $91 \%$ strongly agree or agree) in collaboration with the academic institutions (89\% strongly agree or disagree) as illustrated in Figure 5.

The data clearly shows that there is a need for an industry-led curriculum development process, with a strong agreement of 64\%. This represents twice the responses with strong agreement compared to the average among all available options. Regional academic bodies (75\% agree and strongly agree) and international collaborators (73\% agree and strongly agree) should be involved in the development of curricula and content for RE education programmes.

${ }^{30}$ Pushpendra K. Jain, Edward M. Lungu, and Buti Mogotsi, "Renewable energy education in Botswana: needs, status and proposed training programs," Renewable Energy 25 (January 2002): 115-129. https://doi.org/10.1016/S0960-1481(01)00004-0. 


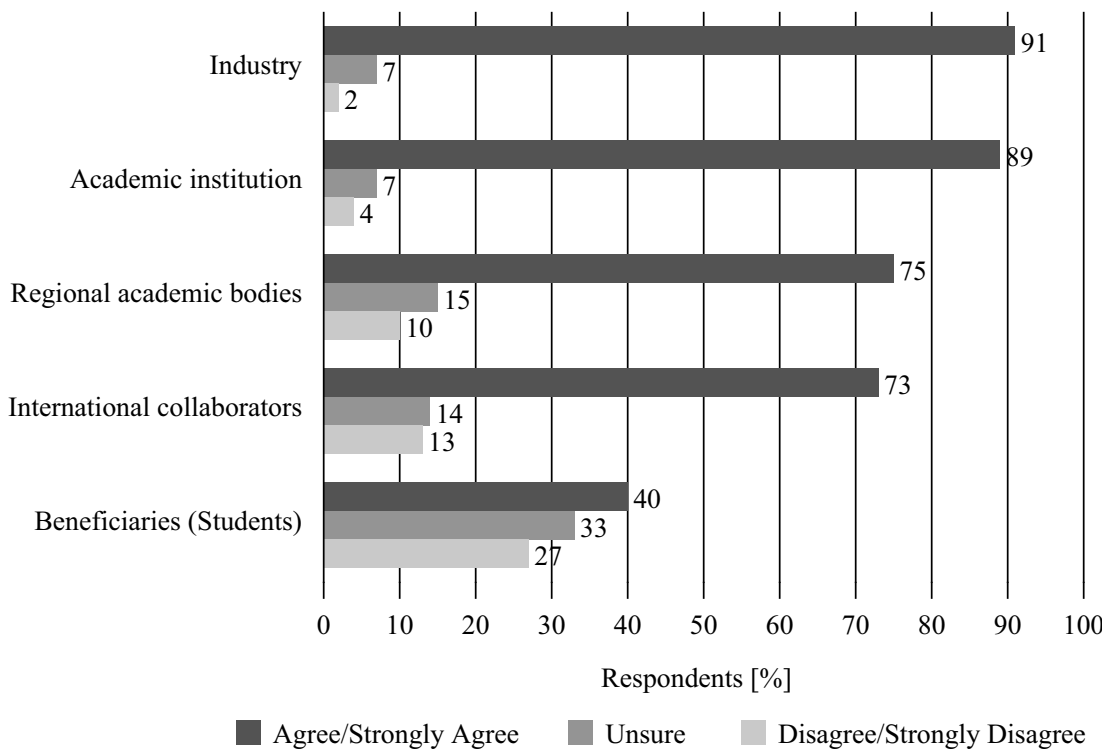

Figure 5

Parties to be involved in the decision-making process of RE programs contents

Regarding the specific competence areas, a general agreement across all countries was found, the differences being in the intensity of agreement only. This data is illustrated in a content requirement matrix, showing the content preferences for the different countries (Figure 6).

More than $75 \%$ of the respondents in all countries agree or strongly agree with the relevance of the specific competence areas. As outliers, the areas of wind energy and hydropower systems were rated between $50 \%$ and $75 \%$ in Botswana, which can be related to the low potential of these resources in that country. 


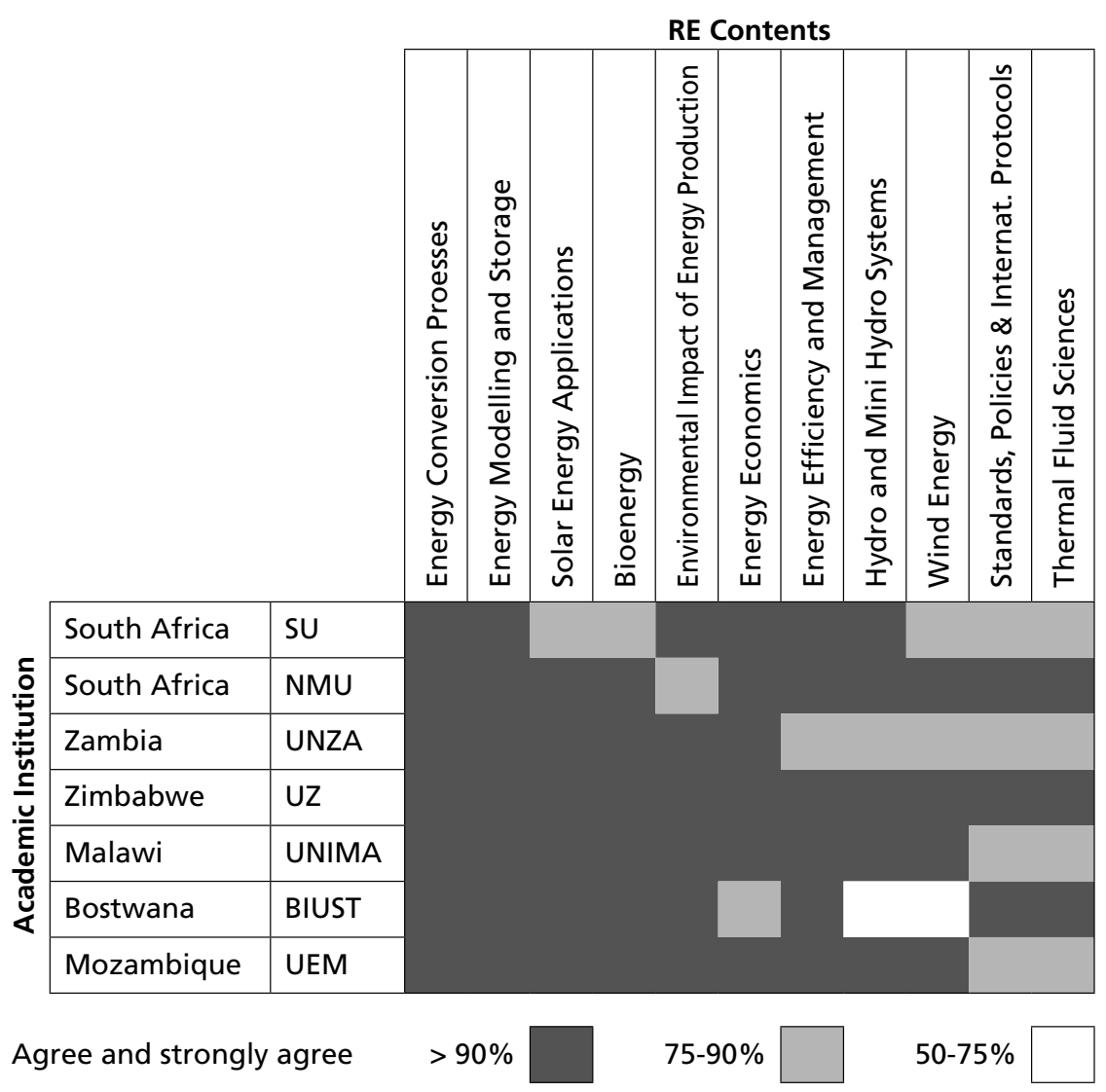

Figure 6

RET content matrix for RE programmes in the participating Southern Africa countries

\section{Evolution of competencies and meta-profile}

From the general characteristics of technology-based qualifications, twenty-two competencies, encompassing both generic and specific competencies, were defined, as listed in Table 1, modelled around the work cited in Section 2. For creating relationships and incorporating the results of the survey described in Section 3, the characteristics enumerated in the list of generic and specific competencies were condensed into six generalised 
elements shown in Table 2, and are termed the key competencies. Based on the outcome of the survey results, it was possible to assign these key competencies to the survey questionnaire themes and evaluate their priorities using the scores from the stakeholder responses. The assignment of the generic and subject-specific competencies to the key competencies in this work is shown in the last column of Table 1, where the numbers in the second column refer to the section numbers of the questionnaire theme.

\section{Table 1}

Generic and subject-specific competencies for the undergraduate RE qualification

\begin{tabular}{|c|c|c|c|}
\hline & Generic and Subject-specific competence & $\begin{array}{l}\text { Related Key } \\
\text { Competencies } \\
\text { (from Table 2) }\end{array}$ & Survey theme \\
\hline 1 & $\begin{array}{l}\text { Have basic know-how in mathematics, } \\
\text { communication and computing }\end{array}$ & 1,5 & \\
\hline 2 & $\begin{array}{l}\text { Have basic engineering know-how in } \\
\text { the field of mechanical and electrical } \\
\text { engineering }\end{array}$ & 1 & \\
\hline 3 & $\begin{array}{l}\text { Ability to do engineering work by } \\
\text { applying basic methods }\end{array}$ & 1 & \\
\hline 4 & $\begin{array}{l}\text { Ability to apply knowledge of the basic } \\
\text { and applied sciences of renewable } \\
\text { energy systems }\end{array}$ & 2 & \\
\hline 5 & $\begin{array}{l}\text { Ability to identify, evaluate and } \\
\text { implement the most appropriate RE } \\
\text { technologies for the context at hand }\end{array}$ & $2,3,4$ & \\
\hline 6 & $\begin{array}{l}\text { Capacity to create, innovate and } \\
\text { contribute to RE technology } \\
\text { development }\end{array}$ & 2,3 & $\begin{array}{l}\text { Challenges for } \\
\text { RE and current } \\
\text { issues }\end{array}$ \\
\hline 7 & $\begin{array}{l}\text { Capacity to conceive, analyse, design } \\
\text { and manufacture RE products and } \\
\text { systems }\end{array}$ & 3,4 & $\begin{array}{l}\text { Manufacturing } \\
\text { capacity }\end{array}$ \\
\hline 8 & $\begin{array}{l}\text { Skills in planning and executing RE } \\
\text { projects }\end{array}$ & 2,4 & \\
\hline 9 & $\begin{array}{l}\text { Capacity to supervise, inspect and } \\
\text { monitor renewable energy systems }\end{array}$ & 2,4 & \\
\hline 10 & $\begin{array}{l}\text { Capacity to operate, maintain and } \\
\text { rehabilitate renewable energy systems }\end{array}$ & 4,5 & \\
\hline
\end{tabular}




\begin{tabular}{|c|c|c|c|}
\hline & Generic and Subject-specific competence & $\begin{array}{l}\text { Related Key } \\
\text { Competencies } \\
\text { (from Table 2) }\end{array}$ & Survey theme \\
\hline 11 & $\begin{array}{l}\text { Skills in evaluating the environmental } \\
\text { and socio-economic impact of } \\
\text { renewable energy projects }\end{array}$ & 2,5 & $\begin{array}{l}\text { Purpose of RE } \\
\text { education }\end{array}$ \\
\hline 12 & $\begin{array}{l}\text { Capacity to model and simulate } \\
\text { renewable processes and systems }\end{array}$ & $2,3,4$ & $\begin{array}{l}\text { Energy } \\
\text { modelling } \\
\text { capacity }\end{array}$ \\
\hline 13 & $\begin{array}{l}\text { Skills in selecting, mobilising and } \\
\text { administering material resources, tools } \\
\text { and equipment cost-effectively }\end{array}$ & & \\
\hline 14 & $\begin{array}{l}\text { Capacity to integrate legal, economic } \\
\text { and financial aspects indecision-making } \\
\text { in RE projects }\end{array}$ & 4,5 & $\begin{array}{l}\text { Energy } \\
\text { economics }\end{array}$ \\
\hline 15 & $\begin{array}{l}\text { Capacity for spatial abstraction, graphic } \\
\text { representation and engineering } \\
\text { drawings. }\end{array}$ & 1 & \\
\hline 16 & $\begin{array}{l}\text { Providing resolutions to societal } \\
\text { problems for sustainable development }\end{array}$ & 4,5 & $\begin{array}{l}\text { Purpose of RE } \\
\text { education }\end{array}$ \\
\hline 17 & $\begin{array}{l}\text { Skills in safety and risk management in } \\
\text { renewable energy systems }\end{array}$ & 2,4 & \\
\hline 18 & $\begin{array}{l}\text { Skills in using information technologies, } \\
\text { software and tools for renewable } \\
\text { energy }\end{array}$ & 5 & \\
\hline 19 & $\begin{array}{l}\text { Capacity to interact with } \\
\text { multidisciplinary groups towards } \\
\text { developing integrated solutions }\end{array}$ & 5 & $\begin{array}{l}\text { Purpose of RE } \\
\text { education }\end{array}$ \\
\hline 20 & $\begin{array}{l}\text { Skills in employing quality control } \\
\text { techniques in managing materials, } \\
\text { products, resources and services }\end{array}$ & 2,5 & \\
\hline 21 & $\begin{array}{l}\text { Capacity to conduct life cycle assessment } \\
\text { for products and systems }\end{array}$ & 2 & \\
\hline 22 & $\begin{array}{l}\text { Capacity to employ science and } \\
\text { engineering skills to transform local } \\
\text { national resources into products or } \\
\text { services through value addition }\end{array}$ & 4,5 & $\begin{array}{l}\text { Challenges for } \\
\text { RE and current } \\
\text { issues }\end{array}$ \\
\hline 22 & $\begin{array}{l}\text { Ability to further qualify into } \\
\text { postgraduate programme }\end{array}$ & 6 & \\
\hline
\end{tabular}


Table 2

List of key competence areas

\begin{tabular}{|c|l|}
\hline 1 & \multicolumn{1}{|c|}{ Key Competence Area } \\
\hline 2 & $\begin{array}{l}\text { Capacity to create(a), innovate (b) and contribute(c) to RE technology } \\
\text { development }\end{array}$ \\
\hline 2 & $\begin{array}{l}\text { Capacity to conceive(d), analyse(e), design(f) and manufacture(g) RE } \\
\text { products and systems }\end{array}$ \\
\hline 3 & $\begin{array}{l}\text { Skills in evaluating(h) the environmental and socio-economic impact of } \\
\text { renewable energy projects }\end{array}$ \\
\hline 4 & Capacity to model(i) and simulate(j) renewable processes and systems \\
\hline 5 & $\begin{array}{l}\text { Capacity to integrate legal, economic and financial aspects in decision- } \\
\text { making in RE projects }\end{array}$ \\
\hline 6 & Providing resolutions to societal problems for sustainable development \\
\hline
\end{tabular}

The first four key competence areas listed in Table 2, having a relatively higher scoring, were then crystallised into the main elements of the curriculum, the outcome of which is the statement of the core competence of the curriculum, articulated as "Analysis and creation of RE products and systems and evaluation of their impact". This statement is characterised by three clusters: create, analyse and evaluate. Cluster 1, 'create RE products and systems' embodies the combined elements a, b, c, d, f, and g, identified and so denoted in Table 2. Similarly, Cluster 2, "analyse RE products and systems", combines elements grouping of $\mathrm{e}, \mathrm{i}$, and $\mathrm{j}$, and Cluster 3 , "evaluate impact of RE products and systems", has the element $h$. These descriptive clusters provide a natural flow into the intended learning outcomes (related to the learning taxonomy level) given in Figure 2.

In completing the meta-profile, adding and overlaying the generic and specific competence clusters leads to the star-planet system model of the programme as shown in Figure 7. The group of core competence skills forms the star of the planetary system, driving the planets at three orbital levels, with the first orbit comprising a set of three planets of hard skills (H1 $-\mathrm{H} 3$ ), the second orbit comprising a set of three planets of soft skills (S1 S3), and the third orbit comprising a set of three planets of attitudes attributes $(\mathrm{A} 1-\mathrm{A} 3)$. 


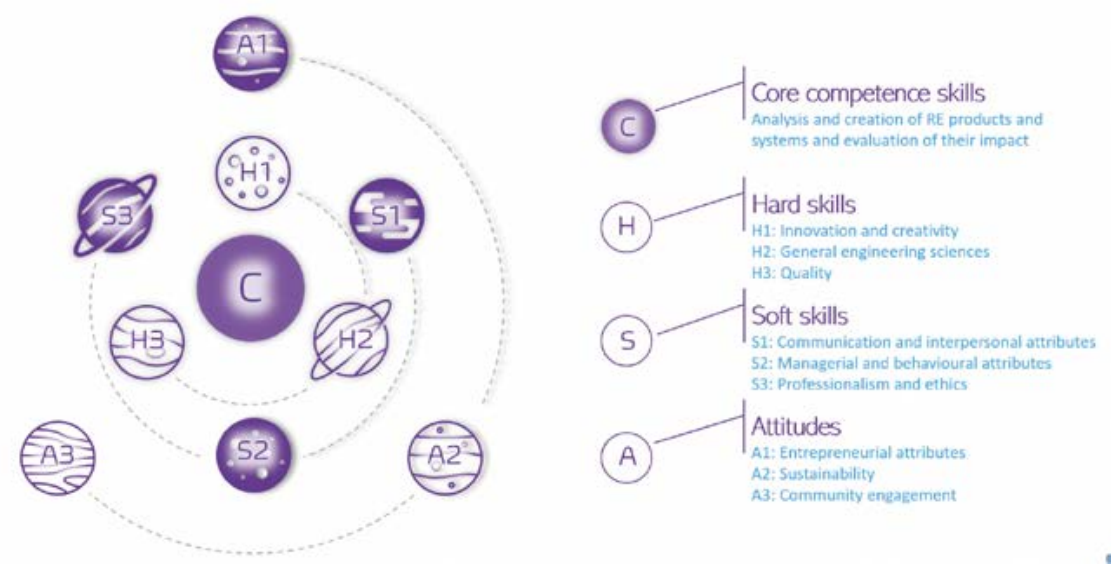

Figure 7

Planetary representation of meta-profile - case of Renewable Energy

One outcome which was absent in the general characteristics of existing graduate competencies in engineering and science programmes, but produced a strong showing in the survey results, was a requirement for entrepreneurial skills. This aspect, together with the requirement for working with communities, is seamlessly accounted for by adoption of the recommendation of Sackey et al. ${ }^{15}$ in the third planetary orbit (A1-A3). This approach provides an effective way to identify and develop a set of core competencies for the programme. Clearly, the role and influence of stakeholders is substantial and thus a careful design of the survey instruments, which is the route for wider stakeholder participation, is cardinal. This approach can be recommended for application elsewhere as regions, and indeed the continent, move towards the development of sector-based, intra-regional harmonised engineering programmes. ${ }^{31}$

31 Juma Shabani, Peter Okebukola, and Olusola Oyewole. "Qualification Recognition and Frameworks in Africa," in Regionalization of African Higher Education: Progress and Prospects, ed. Jane Knight and Emnet T. Woldegiorgis. Rotterdam: Sense Publishers, 2017: 135-150. https://doi.org/10.1007/978-94-6300-956-0. 


\section{Conclusions and recommendations}

A methodology has been proposed for the development of sector-specific technology-based qualification profiles that addresses harmonisation on two fronts. Firstly, on ensuring industrialisation and labour market orientation, and secondly, on ensuring regional equivalence and comparability of qualifications. This approach was found to be necessary in a developingcountry context due to the foremost need to nucleate enterprises, as opposed to the developed-country context which makes use of an existing industrial base as part of the competence enabling trajectory of graduates. In this light, primary stakeholders in the profiling stage of a qualification include those that set the industrialisation strategies and plans of countries.

The methodology uses established processes which are extended in terms of its stakeholder engagement criteria focussing on industrialisation within a developing-country context. It was applied to the case of Renewable Energy in Southern Africa, with the aim of developing specialised, sectorspecific, qualifications at undergraduate level in particular.

The study initially defined a set of twenty-two generic and specific competences in a non-disaggregated manner, directed at the sector, which were then grouped into six key competence areas. These six key competencies areas were further transformed, for the purpose of developing a meta-profile for the qualification, into a core competence (as the centre of the planetary system), followed by sets of hard, soft and attitudinal skills.

The planetary description of the meta-profile thus revealed a core set of competencies related to the analysis, creation and evaluation of technologyspecific products and systems and the evaluation of their impact. Such competences cut across the various technologies within the sector, and links to the resources and industrialisation potential that exist within specific locations/countries. The first two planetary orbits encompass an integration of hard engineering and science related skills with soft communications and management related skills. The outer planetary orbit encompasses skills related to entrepreneurship and sustainable development.

\section{Bibliography}

Agbaje, Ganiyu, Omowumi Alabi, and Etim Offiong. "Education and Training in Applied Remote Sensing in Africa: The ARCSSTE-E Experience." ISPRS International Journal of Geo-Information 8, no. 350 (2019): 1-14. https://doi. org/10.3390/ijgi8080350. 
Anderson, Lorin W., David R. Krathwohl, Peter W. Airasian, and Kathleen A. Kruikshank. A Taxonomy for Learning, Teaching, and Assessing: A Revision of Bloom's Taxonomy of Educational Objectives. New York: Longman, 2001.

Chikuni, Edward, Francisco Goncalves-Longatt, Emanuel Rashayi, and Ogbonnaya I. Okoro. "Power system, substation, automation and the smart grid, how should universities react?" In Proceedings of the IEEE International Conference on Industrial Technology (ICIT). Cape Town, 2013: 905-909. https://doi.org/ 10.1109/ICIT.2013.6505791.

Suñé, Letícia Soares de Vasconcelos Sampaio, and Roberto de Armas Urquiza. "Compared education study: curriculum design for the development of competences." Tuning Journal for Higher Education 3, no. 2 (2016): 319-346. https://doi.org/10.18543/tjhe-3(2)-2016pp319-346

Ebrahimi, Masoumeh, Amleset Kelati, Emma Nkonoki, Aron Kondoro, Diana Rwegasira, Imed Ben Dhaou, Ville Taajamaa, and Hannu Tenhunen. "Creation of CERID: Challenge, Education, Research, Innovation, and Deployment in the Context of Smart MicroGrid." In Proceedings of the 2019 IST-Africa Week Conference (IST-Africa). Nairobi, May 2019: 1-8.

Elamrani, Ahmed, Guillaume Amadji, Jean Ndimubandi, Christopher M. Tankou, Samuel K. Offei, Taky Hortense, Atta Dialo et al. "Meta-profile development using the Tuning Methodology to support Agricultural Sciences Training in Africa." Paper presented at the International Conference on Engineering Education and Research, Marrakesh, July 2013. https://www.researchgate.net/ publication/330545209_Meta-profile_development_using_the_Tuning_ Methodology_to_support_Agricultural_Sciences_Training_in_Africa.

Elkin, Graham. "Competency-based human resource development." Industrial and Commercial Training 22, no.4 (April 1990): 20-25. https://doi. org/10.1108/00197859010137009.

ENAEE (European Network for Accreditation of Engineering Education). "EUR-ACE Framework Standards for the Accreditation of Engineering Programmes.” 2018. https://www .enaee.eu/eur-ace-system/standards-and-guidelines/\#standards-andguidelines-for-accreditation-of-engineering-programmes.

González, Julia, and Maria Yarosh. "Building Degree Profiles. The Tuning Approach." Tuning Journal for Higher Education 1, no. 1 (July 2014): 37-69. http://dx.doi.org/10.18543/tjhe-1(1)-2013pp37-69.

Hahn, Karola, and Damtew Teferra. "Tuning as Instrument of Systematic Higher Education Reform and Quality Enhancement: The African Experience." Tuning Journal for Higher Education 1, no. 1 (2014): 127-163. http://dx.doi. org/10.18543/tjhe-1(1)-2013pp127-163.

IEA. "World Energy Outlook 2014.” https://www.iea.org/reports/world-energyoutlook-2014

Incekara, Ahmet, Tugba Guz, and Gulden Sengun, "Measuring the Technology Achievement Index: Comparison and Ranking of Countries". Journal of Economics, Finance and Accounting 4, no. 2 (2017): 165-174. http://doi. org/10.17261/Pressacademia.2017.446. 
IRENA. "Renewable Energy in the Water, Energy \& Food Nexus." 2015. https:// www.irena.org/publications/2015/Jan/Renewable-Energy-in-the-WaterEnergy--Food-Nexus.

Jain, Pushpendra K., Edward M. Lungu, and Buti Mogotsi, "Renewable energy education in Botswana: needs, status and proposed training programs." Renewable Energy 25 (January 2002): 115-129. https://doi.org/10.1016/S09601481(01)00004-0.

Jonker, Lewis, Pieter van der Zaag, Bekithemba Gumbo, Johan Rockström, David Love, and Hubert H. G. Savenije. "A regional and multi-faceted approach to postgraduate water education - the Watered experience in Southern Africa." Hydrology and Earth System Sciences 16 (November 2012): 4225-4232. https:// doi.org/10.5194/hess-16-4225-2012.

Kouwenhoven, Wim. "Competence-based curriculum development in Higher Education: a globalised concept?" In Technology Education and Development, edited by Aleksandar Lazinica and Carlos Calafate. (Rijeka: InTech Open, 2009), 1-22.

Martikka, Mikko, Roope Husgafvel, Olli Dahl, Andrade Egas, and Natasha Ribeiro. "Study Module Development on Environmental Engineering - Experiences from Mozambican and Finnish Higher Education Collaboration." In Proceedings of the International Conference Environment and Water Resource Management (AfricaEWRM) (Gaborone, 2014): 35-43.

Pegels, Anna. "Renewable energy in South Africa: Potentials, barriers and options for support." Energy Policy 38 (2010): 4945-4954. https://doi.org/10.1016/j. enpol.2010.03.077.

REN21. "Renewables 2015 Global Status Report.” https://www.ren21.net/wpcontent/uploads/2019/05/GSR2015_Full-Report_English.pdf.

REN21. "SADC Renewable Energy and Energy Efficiency Status Report." 2018. https://www.ren21.net/2018-sadc-renewable-energy-and-energy-efficiencystatus-report/.

Sackey, Samuel M., Venkata R. Ancha, Moses P.M. Chinyama, Charles A. Onana, Raïdandi Danwe, Mohammad M. Megahed, Béatrice Delpouve, Shadreck Chama et al. "Collaborative meta-profile development to harmonise mechanical engineering education in Africa." Tuning Journal for Higher Education 2, no. 1 (December, 2014): 161-178. http://dx.doi.org/10.18543/tjhe-2(1)2014pp161-178.

Shabani, Juma, Peter Okebukola, and Olusola Oyewole. "Qualification Recognition and Frameworks in Africa." In Regionalization of African Higher Education: Progress and Prospects, edited by Jane Knight and Emnet Woldegiorgis. Rotterdam: Sense Publishers, 2017: 135-150. https://doi.org/10.1007/978-946300-956-0.

Staak, Anthony, and Raynitchka Tzoneva. "The design of a master's curriculum in smart grid technology within the Erasmus+ K2 DAMOC project." In Proceedings of the 11th International Conference on Engineering and Business Education (ICEBE). Szczecin, 2018: 27-34. 
Tuning Academy. "Feasibility Study into the Relevance of a Tuning Approach for Higher Education in Africa." Final Report, 2011. http://tuningacademy.org/ tuning-africa-feasibility-study/?lang=en .

Woldegiyorgis, Ayenachew A. "Harmonization of higher education in Africa and Europe: Policy convergence at supranational level." Tuning Journal for Higher Education 5, no. 2 (May 2018): 133-157. http://dx.doi.org/10.18543/tjhe-5(2)2018pp133-157.

Woldegiorgis, Emnet T., "Conceptualizing Harmonization of Higher Education Systems: The Application of Regional Integration Theories on Higher Education Studies." Higher Education Studies 3, no. 2 (2013): 12-23. https://doi. org/10.5539/hes.v3n2p12.

Woldegiorgis, Emnet T., Regionalization of Higher Education in Africa: The Operationalization of the African Union Higher Education Harmonization Strategy (Berlin: LIT Verlag, 2017): 173-187.

The World Bank. "State of Electricity Access Report (SEAR) 2017." https:// documents.worldbank.org/en/publication/documents-reports/ documentdetail/364571494517675149/full-report.

\section{About the authors}

WILFRIED ZÖRNER (Wilfried.Zoerner@thi.de) holds a Ph.D. degree as Dr.-Ing. in Mechanical Engineering (Solar Energy Systems) from the Technical University Munich, Germany. Besides his current position as Professor for Product Development and Design (since 1998), including teaching in Renewable Energy, Solar Engineering, Product Design, Design Elements, Pneumatics and Cost Management, he is the Head of Institute at the Institute of new Energy Systems (InES) at Technische Hochschule Ingolstadt, Germany. His research works includes, but is not limited to, the responsibility for numerous national and international research projects in the area of bio-energy, solar energy and energy systems technology. Prof. Zörner has built up a strong network of local, Bavarian state, German federal and international funding institutions. He has seven years of professional experience in the engineering and plant construction industry, is a member of numerous tasks within the Solar Heating and Cooling Programme of the International Energy Agency, the advisory committee of the German Solar Thermal Technology Platform (DSTTP) and of numerous scientific conference committees. Prof Zörner provides consultancy for industry in the field of (renewable) energy provision and energy efficiency.

NAWAZ MAHOMED (nawaz@sun.ac.za) is Associate Professor, Department of Mechanical and Mechatronic Engineering at Stellenbosch University, South Africa. He obtained his bachelors and masters degrees in engineering at the University of Cape Town, after which he completed his $\mathrm{PhD}$ in the field of computational mechanics at the Institute for Fundamental Technological Research of the Polish Academy of Sciences in Warsaw. He initially started his 
career as an academic from 1995 until 1999 at Cape Peninsula University of Technology (CPUT). He then spent the following 10 years at various organisations which included the Council for Scientific and Industrial Research, the Department (Ministry) of Science and Technology and the Institute for Maritime Technology (ARMSCOR), before being appointed as Dean of the Faculty of Engineering at CPUT in 2010. He joined Stellenbosch University in 2015, mainly working in the fields of solidification, heat treatment and performance optimisation of steel.

ACKIM ZULU (ackim.zulu@unza.zm) is Senior Lecturer in the Department of Electrical and Electronic Engineering at University of Zambia (UNZA) with research interests in energy \& power and in education development. Before joining UNZA in 1993, he worked for one year for the Zambia Consolidated Copper Mines as Senior Assistant Engineer. He has a PhD degree in electrical machines from Newcastle University (UK). He is a member of the Institution of Engineering and Technology (IET) (UK), the Institute of Electrical and Electronic Engineers (IEEE) (USA) and the Power and Energy Society of IEEE.

TOBIAS BADER (badert@biust.ac.bw) is Lecturer in the Department of Mechanical, Energy and Industrial Engineering at Botswana International University of Science and Technology (BIUST) with research interests in renewable energy, sustainable urban building energy and engineering education. Before joining BIUST in 2017, he worked for five years as Research Engineer at the Institute of new Energy Systems in Germany and held positions in Quality Management and Technology Management in the Industry for 6 years. He has a $\mathrm{PhD}$ degree in Mechanical Engineering with specialisation in Solar-Air-Conditioning from De Montfort University Leicester (UK) in Collaboration with TH Ingolstadt (Germany). He is a YEP Member of the World Energy Council and Founding Secretary of the Renewable Energy Association Botswana (REAB).

CHIFUNDO TENTHANI (ctenthani@poly.ac.mw) is Senior Lecturer in the Department of Physics and Biochemical Sciences at the Malawi Polytechnic of the University of Malawi with research interests in renewable energy, and climate change. He has a Master of Science degree in Renewable Energy with specialisation in Solar from Makerere University (Uganda). He is a Country Representative for Malawi for the African Network for Solar Energy (ANSOLE). He is also the Country Counterpart for IAEA's AFRA 2010 Project for Malawi.

BOAVENTURA CHONGO CUAMBA (boaventura.cuamba@ gmail.com) holds a $\mathrm{PhD}$ degree in Energy Physics from the Northumbria University in the UK, in 1996. He is now Professor of Renewable Energy Systems at the Eduardo Mondlane University in Maputo, Mozambique. He teaches different Physics modules at both undergraduate and postgraduate levels, as well as courses in the renewable energy. Professor Cuamba has been participating in many national and international research programmes in the field of renewable energies, funded by organisations like the Norwegian Development Agency, NORAD, the Swedish Development Agency, SIDA, the German Development Agency, DAAD, among others. He also participates in several consulting activities in the 
energy field with organisations like the World Bank, the African Development Bank, and the European Union, among others. He is a member of professional associations like the German Physical Society (Deutsche Physikalische Gesellschaft-DPG), of the British Institute of Physics (IoP) and of the International Solar Energy Society (ISES). He is Member of the Editorial Advisory Board of the International Journal "Management of Environmental Quality (MEQ)" from Emerald Publisher and member of several scientific conference Committees.

HILTON CHINGOSHO (chingoshorus@gmail.com) is a registered engineer and currently a Lecturer in the Department of Mechanical Engineering at the University of Zimbabwe, with research interests in Renewable Energy, Energy Storage, Energy Efficiency, Management and Auditing. Before joining UZ in 2016, he worked as a Projects Officer for UNICEF, Practical Action and as a Lead Energy consultant for HIVOS, a Netherlands Humanist Development Organisation. He is a PhD candidate and a holder of a Master of Science Degree in Renewable Energy from University of Zimbabwe (UZ). He is a Certified Energy Manager CEM (USA), an International Member of the Association of Energy Engineers (USA) and a professional member of the Zimbabwe Institution of Engineers. 


\title{
Meta-profile and competencies for harmonisation of higher education in sector-specific technology areas: A case study of Renewable Energy in Southern Africa
}

\author{
Wilfried Zörner, Nawaz Mahomed, Ackim Zulu, Tobias Bader, \\ Chifundo Tenthani, Boaventura Cuamba, and Hilton Chingosho
}

doi: http://dx.doi.org/10.18543/tjhe-8(1)-2020pp75-97

\section{Copyright}

Copyright for this article is retained by the Publisher. It is an Open Access material that is free for full online access, download, storage, distribution, and or reuse in any medium only for noncommercial purposes and in compliance with any applicable copyright legislation, without prior permission from the Publisher or the author(s). In any case, proper acknowledgement of the original publication source must be made and any changes to the original work must be indicated clearly and in a manner that does not suggest the author's and or Publisher's endorsement whatsoever. Any other use of its content in any medium or format, now known or developed in the future, requires prior written permission of the copyright holder. 